\title{
Bill AtKin: Colleague, Mentor, TEACHER, FRIEND
}

\author{
Tony Angelo, Geoff McLay and Bevan Marten*
}

As Bill tells the story, he got his job at Victoria University of Wellington in the following manner: one day in one of the last classes of his degree, the professor put a slide on the overhead projector with the names "of some people who might like to consider becoming assistant lecturers". Bill's name was on the list. He applied, and has never looked back. Below, three of Bill's close colleagues discuss their experiences of Bill's friendship and guidance.

\section{TONY ANGELO}

The first clear recollection I have of Bill Atkin is from the early 1970s - probably about July 1973. The occasion was a familial-like gathering of staff in the 14 Kelburn Parade staff library cum seminar room. Bill and Virginia were there chatting with colleagues. In those days, about half of the Law Faculty staff occupied 14 and 16 Kelburn Parade - there were perhaps 10 colleagues with two secretaries and at least one tutorial room on the ground floor. The other members of the Faculty were probably still in the Hunter Building. The Faculty was eventually (semi) brought together in one place in the Rankin Brown Building - on the 6th and 8th floors, but not the 7th.

On my return from Mauritius to fulltime Faculty duties in 1975, I continued my interests in family law and, in due course, began a number of research collaborations with Bill Atkin. It is interesting to recall that, at that time, family law was a growth area, and one dominated by Professor Don Inglis at Victoria and Professor Dick Webb at Auckland.

It was an exciting time for law reform generally, but especially for family law. The Hanan/Robson master plan was being worked out. ${ }^{1} 1969$ had seen the enactment of the Minors' Contracts Act and the Status of Children Act; they were complemented in 1970 by the Age of Majority Act. Then came a flush of substantial statutes - the Children and Young Persons Act 1974, the Matrimonial Property Act 1976 and the Domicile, Family Courts and the Family Proceedings

* Professor, Professor, and Lecturer, School of Law, Victoria University of Wellington.

1 BD Inglis and AG Mercer (eds) Family Law Centennial Essays (Sweet \& Maxwell, Wellington, 1967), especially JR Hanan "The future of family law". 
Acts in 1980. In retrospect, it was a breath-taking era - and preparing and presenting parliamentary submissions was a major task in itself.

Bill and I made many joint submissions to Parliament on the family law reforms of that time. All of this was assisted by the administrative knowledge about select committee procedures of Bill's father who was then working at the House of Representatives. Among the pieces of legislation for which major submissions were made (and sometimes there was more than one on the same Bill) were the Matrimonial Property Act 1976, the Family Courts Act 1980 and the Family Proceedings Act 1980. I remember, among other things, very extensive submissions being made to a select committee on methods of dealing with those who defaulted on maintenance payments, and whether having the matter handled through the Department of Inland Revenue would be a good alternative to the then judicial process.

A spin-off of the parliamentary Bills research was academic publication. At least one article was judicially noted and has been something of an evergreen in that it is still cited. ${ }^{2}$ This was the period when Bill cemented his family law research position.

That was Bill's family law interest. Not to be forgotten however is the massive contribution (a continuing one) to the Victoria University of Wellington Law Review (VUWLR). Bill has been a supporter of the Law Review from then, forever - as a Committee member, as Editor and as a proud defender. And mention must also be made of the substantial commitment made by Bill to the LLB(Hons) programme.

Bill and Virginia are noted for their ever warm hospitality to visiting academic colleagues and to senior students alike. Our thanks to them.

Bill is a person who is always there when good counsel is needed. He is a good friend and academic colleague.

Of Bill's role as a teacher and mentor, I leave my young colleagues to speak.

\section{GEOFF MCLAY}

I met Bill in March 1988. I burst in 10 minutes late to our first small group class of the year, held in the (consigned only to memory) confines of the Laby Prefab. Looking back, that class touched on much that would follow: service, family and cricket. Bill explained that he had volunteered to take on the course, as the Faculty had found itself a course short. Bill had just got back from Disneyland where he and his wife had taken their seven year old son Matthew, who even then was a mad keen cricketer. In the 27 years since, I have never known Bill not to shine when

2 AH Angelo and WR Atkin "A Conceptual and Structural Overview of the Matrimonial Property Act 1976" (1977) 7 NZULR 237, cited in Reid v Reid [1979] 1 NZLR 572 (CA) at 600. 
talking about his family: his parents, Virginia, Matthew, more recently Julie, and most recently Beau. Service remains a key in his approach to his role at the University, and cricket remains at the heart of our conversations, even after what seems like innumerable summers at the Basin with his father and mine. Bill's other two loves - music and the church - are still, despite those decades of gentle persuasion, a little beyond me, although I have always thought Bill the very image of the Anglican gentleman.

When I entered his classroom I did not know what a tort was, but I was sure that I was pretty disappointed to be studying them; everyone thought then, as some still do, that constitutional law was the game of our town. But all these years later I am still a torts lawyer, a strange profession in a country without personal injury. Partly it was the subject, but I think mostly it is Bill's gentle urgings that kept me involved in the law of torts. For Bill, I think that there is something in the subject that speaks of something a little higher: that we are all somehow responsible for others. While I fear that long ago I left the house that the neighbour principle built, I noticed as recently as last year - as I was explaining to the students that Bill and I didn't actually necessarily agree on everything - I did feel a little pang that while being right might be one thing, disagreeing with Bill was another.

After torts, Bill found me a holiday job at the legendary Law Reform Division, my first inside look at the world of law reform. Bill supervised my legal writing, a process of countless red circles and squiggles, until it got published. I was Bill's research assistant on Living Together Without Marriage: The Law in New Zealand ${ }^{3}$ (which was perhaps a little more legally focused on de facto relationships than the title promised), and the occupant of his office on the eighth floor of Rankin Brown for a summer. He introduced me to the current Attorney-General, and I magically ended up as summer clerk at Brandon Brookfield. In short, Bill made opportunities for me when there was no need or expectation that he should (and quite often when I didn't realise that was what he was doing). As Bevan writes below, I was not alone in this, and throughout it all Bill exhibited what is the mark of a true teacher: satisfaction in the student's accomplishment in something that the teacher could have done more easily, and pride when the student did something he couldn't have imagined doing.

For the last 20 years I have been Bill's colleague at the Faculty: an infinity of Faculty meetings, Law Review issues, coffee and, inevitably, sometimes things that both he and I would wish were not part of academic life. Sometimes universities can be less than kind places, and I will always remember one occasion when our University had been less than kind to him. I spent a lap of the Basin explaining my scorched earth approach that would involve Bill resigning from his LLM coordinator's job and taking the summer off, but Bill couldn't do that - students were the point of the job. For Bill, students are not just EFTS (equivalent full time students: the currency of the University) or worse, code numbers on a grade sheet; they are real live people with names and faces.

3 Bill Atkin Living Together Without Marriage: The Law in New Zealand (Butterworths, Wellington, 1991). 
I have been forever shamed in my time teaching with Bill in torts (a class of almost 300 students a year) when he has said "you must remember such and such, third row back, two in on the right", and just as I failed to reimagine this year's class he has added "she just got married", "he finally got a job", "she's at Harvard now", "he's back from Brazil and I'm off to lunch with him".

This issue is a celebration of scholarship, and honours Bill's scholarship. It is right that the VUWLR honours someone without whom I doubt it would exist. But as important as all that scholarship is, the University's main job is growing students. That has always been Bill's greatest contribution. Throughout my time, Bill has been a proofreader of the insensible and calmer of troubled waters. I am not sure where we would have been without him.

\section{BEVAN MARTEN}

I first encountered Bill Atkin in the 2002 torts class. Hundreds of young lawyers have been introduced to this complex and varied branch of law through Bill's teaching - complete with the famous props (the water pistol and the mini cricket bat in particular). Torts also gives Bill an opportunity to teach some of his favourite cases, especially those concerning cricket, ${ }^{4}$ the "itchy underpants" 5 and musical shenanigans. ${ }^{6}$ I remember his lecturing style as proceeding mainly by way of a calm discussion with his students. There are no obvious notes, and just one or two slides from time to time, although key words are chalked up on the blackboard as the class progresses. Despite being faced with 300 students a day when lecturing in this course, and presenting them with just 18odd lectures, Bill manages to learn an impressive number of students' names, along with some indication of their prowess in responding to questions.

During Bill's lectures on false imprisonment I found myself disagreeing with the reasoning of a 1914 decision involving a claim by a miner held below the earth. ${ }^{7}$ Feeling too nervous to articulate this in class, I went to see Bill in his office. It was certainly the first time I had approached a lecturer on that basis, and the fact I felt comfortable approaching Bill speaks to the polite and encouraging manner that characterises all his dealings with students. The courteous reception my unannounced intrusion received (Bill warmly suggested that Herd could be seen as "a decision of its time") gave me the confidence to approach the law with a more critical eye. Bill does not hold office hours, post sign-up sheets for appointments or insist on email contact in advance. His door is always open.

I recall one further example of Bill's dedication to his students' well-being from later in 2002. My ruptured, gangrenous appendix had just been removed, and Bill came to my bedside in

Bolton v Stone [1951] AC 850 (HL); and Miller v Jackson [1977] QB 966 (CA).

Grant v The Australian Knitting Mills [1936] AC 85 (PC).

6 Christie v Davey [1893] 1 Ch 316 (Ch).

7 Herd v Weardale Steel, Coal \& Coke Co Ltd [1915] AC 67 (HL). 
Wellington Hospital with the head torts tutor. They had brought a pile of mooting materials for me: I was into the next round of the junior competition, and they were concerned that I should have time to prepare if I wished. I politely declined, but have never forgotten the gesture.

If I were being cheeky I would say there are three characteristics that will make a student stand out for Bill. One is an interest in social justice. The other two are an engagement with the Christian message and an ear for classical music. I fell into the first category, and in 2003 was working for the local Member of Parliament, Marian Hobbs. Bill must have invited me to coffee at some point, and we have been friends ever since. Knowing Bill involves a lot of coffee (I hope he never sends me an invoice).

Bill helped usher me into the Honours programme and co-supervised my "489" research essay. $\mathrm{He}$ is the consummate supervisor, and has guided countless students through seminars, essays, dissertations and theses. He knows how to broaden his charges' horizons, introducing us to different research techniques such as Official Information Act 1982 requests, interviews requiring Ethics Committee approval and use of the Parliamentary Library. Trusting even the least experienced scholars to engage with complex materials, Bill normally gets excellent results, and a cursory glance at the VUWLR reveals numerous "thank you" notes acknowledging his support.

From the end of 2004 until the end of my time as an undergraduate I was Bill's research assistant, joining the long line of those fortunate enough to occupy this position (Esther Watt, Nathan Crombie, Redmond Kirwan-Jones and many more leading up to the incumbent, Sean Brennan). The work is enjoyable. Bill demands accuracy and thoroughness, but never places his "RAs" under undue pressure, and is always conscious of the competing demands of study. Bill's first instinct, on presenting an RA with a job, is usually to ask if it will cause any conflict with other assignments. He is scrupulous in acknowledging his assistants in all published work, and also through his endless generosity in the form of lunches.

During this period I embarked upon a mission of particular significance. I dragged Bill into Law School early in January 2005, and together we attempted to tidy up his office. Those who have encountered OGB209 at any time in the past decade will know that this was no small undertaking. We managed to fill two large wheelie bins to the brim with paper. Amongst these documents were Bill's School Certificate Latin and French notes from his Wellington College days, although I have subsequently been informed that he later smuggled these off to Geoff McLay for safe keeping. By the end of two days Bill had reached the limits of his patience with my appetite for "recycling", but this campaign is still fondly remembered by Virginia Atkin, who remarks to each new research assistant that my record has yet to be broken.

In addition to his ongoing friendship, Bill's role as my academic mentor continued after Law School when it came time to apply for Masters programmes. I dread to think how many letters of reference Bill has written for various students and colleagues over the decades, but he is a dab hand at it and those he supports often get what they are after. Bill was one of the first people I called 
when I heard about the scholarship I had received to study for my LLM, and by chance he and Virginia were in Cambridge during my first week there. I treasure a photo of me and Bill sitting together, quietly enjoying the stunning interior of King's College Chapel.

Returning to Victoria as a lecturer in August 2012, I was back having coffee with Bill at Cellarvate within hours. From marking my essays, he is now the person providing me with guidance when I confront a new student dilemma, teaching issue or research hiccup. While I am not one of his family law success stories (former RAs Zoë Lawton and David Neild spring to mind here), I owe a lot to Bill as an academic role model. His example has had a large part to play in my choice of career. My junior colleagues and I will never enjoy the lifestyle that characterised the earlier part of Bill's career, where (I am led to believe) summers were longer and the pressure to cram full the balance of one's calendar not so pronounced, but his more traditional scholarly approach will cast a long and comforting shadow over this Faculty.

One example will have to suffice. At a recent Faculty meeting we were introduced to Victoria's new "Auckland office", located in the central city near the University of Auckland's own School of Law. It was presented as an opportunity for this University to expand its course offerings and attract a previously untapped student market. After this presentation Bill calmly spoke of his opposition to this development. It was, he suggested, uncollegial, and an affront to our fellow academics in Auckland. From his brief speech one could discern a great deal of Bill's approach to academic life. It is one where scholars work not in competition, but in a spirit of cooperative inquiry. Where they look not to improve their faculty's ranking at the expense of another, but willingly expend their own time and energy to support each other's efforts. Where students are individuals who populate lecture theatres to experience the challenges of a legal education, and not consumers of a product, populating balance sheets.

It has been a great privilege to study under Bill's supervision, to work for him and to teach with him as a colleague. I look forward to many more years to come. Long black and trim flat white have here! 